\title{
The effect of tidal range on the flushing of ammonium from intertidal sediments of the Tagus estuary, Portugal
}

\author{
Maria Teresa CABRITA a, Fernando CATARINO a , Carlos VALE ${ }^{b}$ \\ ${ }^{a}$ Instituto de Oceanografia da Faculdade de Ciências, Universidade de Lisboa, Campo Grande, 1700 Lisboa, Portugal

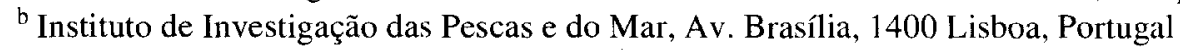

(Received 20 January 1998, revised 15 December 1998, accepted 29 December 1998)

\begin{abstract}
The time-course evolution of ammonium concentration has been examined in the flood water during the first 25 min of tidal inundation. The way this transport fluctuates with the tidal ranges and wind conditions was investigated. Flood water was collected at three sites, located along a transect from the lower to the upper intertidal area of the Tagus estuary. At spring and intermediate tides, the periods of air exposure vary slightly along the transect due to the high tidal amplitude and the flatness of the area, but the upper site remains uncovered at neap tide over the entire tidal cycle. At each site, sampling was performed at different tidal ranges covering the neap-spring tidal cycle and wind conditions. Ammonium was determined in the flood water at short time intervals: 1, 2, 3, 4, 5, 10, 15, 20 and $25 \mathrm{~min}$. A clear pattern was observed along the transect: considerable quantities of ammonium were exported from the sediment to the water column at the beginning of the inundation, ranging from 0.2 to $4.8 \mathrm{mmol} \mathrm{m}^{-2} \mathrm{~d}^{-1}$. The highest transport was recorded at the lower intertidal site under spring tide conditions, which corresponds to the higher energetic situation and shorter emersion period. The lowest transport was observed at the upper intertidal site during the first inundation that followed three days of neap tide and continuous exposure of the sediment to the air. The value rates $\left(0.2-4.8 \mathrm{mmol} \mathrm{m}^{-2} \mathrm{~d}^{-1}\right)$ were one order of magnitude higher than those calculated from molecular diffusion $\left(0.07-0.16 \mathrm{mmol} \mathrm{m}^{-2} \mathrm{~d}^{-1}\right)$. This study points to the importance of the tidal flushing of ammonium from the intertidal sediments, and its spatial and tidal fluctuation. (c) Elsevier, Paris / Ifremer / Cnrs / Ird
\end{abstract}

\section{tidal flushing / ammonium / intertidal sediments / estuary}

Résumé - Effet du marnage sur le transfert de l'ammonium des sédiments dans la zone intertidale de l'estuaire du Tage, Portugal. La concentration en ammonium des eaux a été étudiée dans la zone intertidale de l'estuaire du Tage : évolution pendant les vingt-cinq premières minutes du courant de flot et intensité du largage en fonction des marées et des conditions de vent. L'eau a été prélevée en trois stations, du plus bas au plus haut de la zone intertidale. En eaux vives et par marées intermédiaires, les durées d'exposition à l'air varient légèrement le long de la section étudiée en raison des marées plus fortes et de la déclivité du sol mais, en eaux mortes, la station haute reste découverte pendant tout le cycle des marées. À chaque station, les prélèvements ont été effectués pour différentes marées couvrant le cycle eau morte/eau vive, avec différentes conditions de vent, lors de séquences de $1,2,3,4,5,10,15,20$ et $25 \mathrm{~min}$. Le schéma suivant a été observé : des quantités considérables d'ammonium sont transférées $\left(0,2\right.$ à $\left.4,8 \mathrm{mmol} \mathrm{m}^{-2} \mathrm{j}^{-1}\right)$ du sédiment vers la colonne d'eau à l'arrivée du courant de flot. La plus forte valeur du transfert est enregistrée à la station basse pendant les eaux vives, correspondant à l'énergie maximale et à la plus courte période d'émersion. La plus faible valeur du transfert est observée à la station la plus haute pendant le flot faisant suite à $3 \mathrm{j}$ d'eaux mortes et d'exposition à l'air. Les valeurs mesurées dépassent d'un ordre de grandeur celles calculées à partir de la diffusion moléculaire $\left(0,07 \mathrm{à} 0,16 \mathrm{mmol} \mathrm{m}^{-2} \mathrm{j}^{-1}\right)$. Ces résultats mettent en évidence le rôle de la marée dans l'extraction de l'ammonium des sédiments intertidaux et les variations du largage en fonction de l'espace et des fluctuations de la marée. (C) Elsevier, Paris / Ifremer / Cnrs / Ird

extraction par la marée / ammonium / sédiment intertidal / estuaire 


\section{INTRODUCTION}

Processes in intertidal sediments are strongly influenced by the tide, which produces periodic cycles of emersion-immersion. Semi-diurnal tidal cycles induce constant variations in conditions to the upper layers of the sediment, mainly due to inundation, temperature fluctuation and light exposure. The way flood water spreads over these areas is complex, and mixing associated with this inundation has repercussions on the sediment-porewater equilibria of some chemical species. This tends to accelerate the biogeochemical cycles of some elements.

The transformation and transport of ammonium in these environments is complex, being influenced by morphological, physical, chemical and biological factors [20]. Among them, sediment-water exchanges have strong effects on water column processes [21]. Ammonium in the sediment surface results from: (1) decay of phytoplankton and microphytobenthos [3, 28] and the decomposition of litter material derived from saltmarsh plants; (2) excretion by benthic organisms [17]: and (3) molecular diffusion of $\mathrm{NH}_{4}^{+}$from deeper sediment layers with high ammonium production [2]. In the sediment, ammonium is removed through consumption by benthic primary producers, transformed by nitrifying bacteria in the upper layers and may eventually migrate to the overlying water by diffusion [10]. In the sediments, the ion $\mathrm{NH}_{4}^{+}$is distributed between the pore water and the solid phase, via a reversible sorption equilibrium [19]. In coastal areas, this equilibrium may be easily altered. Seasonal changes of the water column production modify the porewater concentration of nutrients $[1,16,27]$. Bioturbation and irrigation continuously mix porewater with overlying seawater, which breaks down the solid-liquid equilibrium [3]. Falcão and Vale [8] showed that flooding water over the intertidal area of a coastal lagoon causes the release of a significant amount of ammonium from the upper sediment layers. This mechanism tends to follow the tidal oscillation. Sporadically, wind-generated wave action results in sediment resuspension [18] and consequently ammonium desorption from the solids $[9$. 24!.

Most Portuguese coastal ecosystems are characterized by large intertidal areas, which are rhythmically flushed by the tide. The changes in ammonium in these areas occurs on time scales of minutes to hours $[8,22]$. The intensity of the sediment-water exchanges in these areas, its fluctuation with the tidal amplitude are not known. This study reports the evolution of ammonium concentration in flooding water during the first $25 \mathrm{~min}$ of tidal inundation at three sites of the Tagus estuary intertidal areal, and how this transport fluctuates with the tidal ranges and wind conditions.

\section{STUDY AREA}

The Tagus estuary is located on the southwest coast of Portugal and is one of the largest estuaries in Europe, covering an area of about $320 \mathrm{~km}^{2}$ (figure l). The estuary has a large intertidal area (from 20 to $40 \%$ of the total area), mostly consisting of sand and mudflats, and salt marshes. The most extensive intertidal mudflat is situated in the inner broad bay of the estuary (figure 1). The area is shallow with a water column less than $3 \mathrm{~m}$ deep at high tide. The tidal range varies from $1 \mathrm{~m}$ at neap tide to $4 \mathrm{~m}$ at spring tide and causes an important semi-diurnal and fortnightly fluctuation of the water volume in the estuary. During the tidal excursion water progresses laterally and smoothly over these mudflats, as the energy of the incoming tide is dissipated by friction on the inner bay [25]. Occasionally, the inundation is less calm when affected by wind gusts.

The study area - Pancas - is located on this extensive intertidal area of the estuary, which is limited by a narrow salt-marsh fringe on one side and estuarine water on the other. Due to the extent of the mudflats three sampling sites (I, II, III) were selected, along a transect perpendicular to the shoreline (figure 1). The sediments of the study area were not densely colonized by burrowing organisms, like polychaetes, and no gas bubbling was observed. In contrast, benthic microalgae colonized the surface of the sediments at the three sampling sites.

\section{MATERIALS AND METHODS}

\subsection{Field measurements}

The flooding water was collected from the three sampling sites during March 1994. At each site, sampling was performed over the first $25 \mathrm{~min}$ of the tidal inundation: at 1 , $2,3,4,5,10,15,20,25 \mathrm{~min}$ after inundation. The sampling consisted of collection of $500 \mathrm{~mL}$ of flood water from $1 \mathrm{~cm}$ above the sediment surface directly into acid pre-cleaned syringes. All sampling was performed by hand with a team of two persons, and their movement from site to site was made in parallel transects to the sam- 


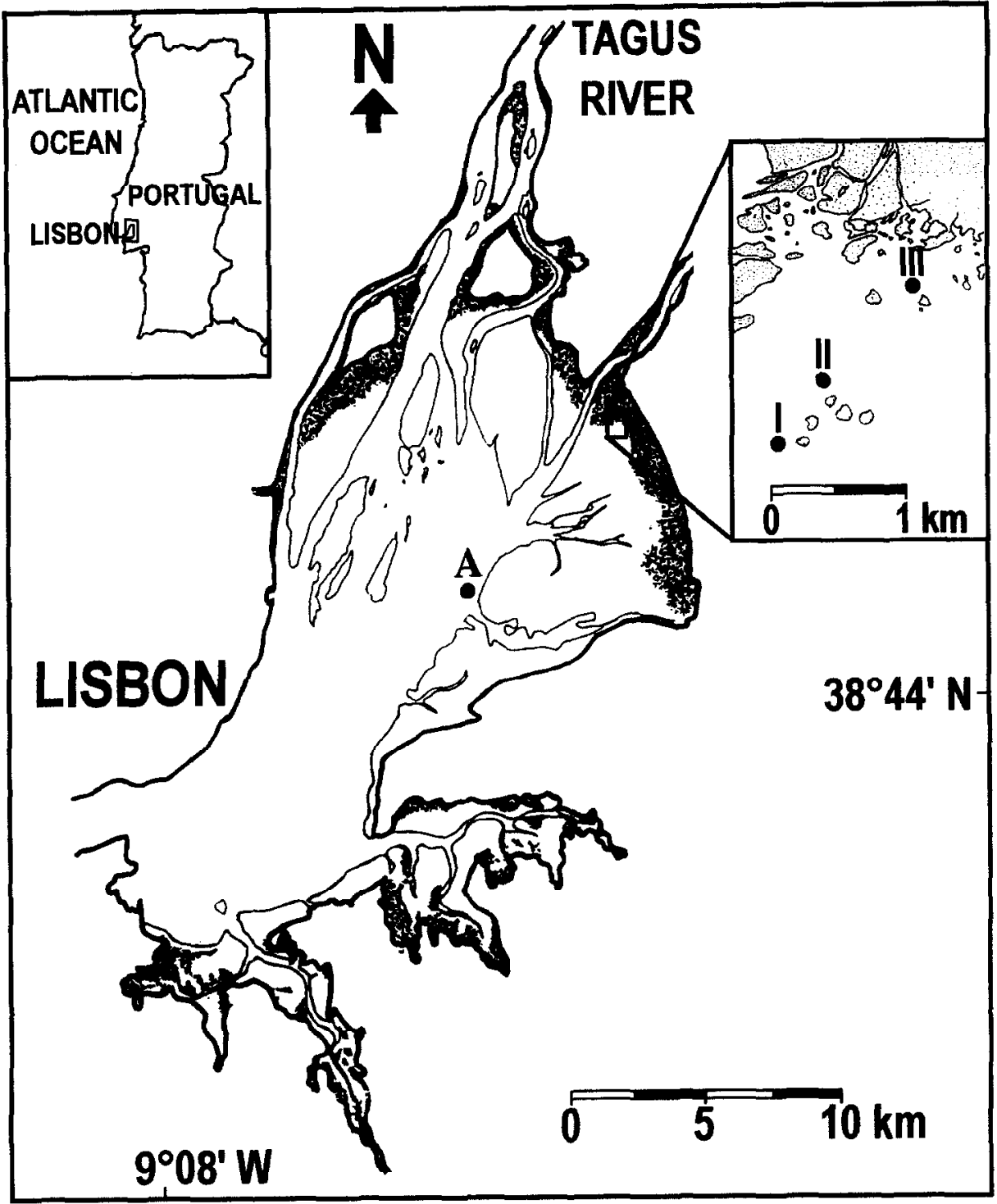

Figure 1. Map of the Tagus estuary showing the sampling sites (I, II, III) located in the intertidal area and site A in the subtidal area. Saltmarshes are represented as dotted areas.

pling axis in order to avoid perturbation of the sediment. The sampling procedure was repeated, for most of the sampling sites, at different tidal amplitudes: $1.1 \mathrm{~m}, 1.9 \mathrm{~m}$, $2.4 \mathrm{~m}, 2.5 \mathrm{~m}, 3.0 \mathrm{~m}$ and $3.9 \mathrm{~m}$. The temperature of the water and sediment was determined in situ, and water height at each site was measured during the $25 \mathrm{~min}$ sampling period. Before the water arrived at each sampling site, the top first $\mathrm{cm}$ of sediment was sampled by hand with a rigid plastic tube $(3.6 \mathrm{~cm}$ diameter) for determination of water content, organic matter content and dis- solved ammonia in the sediment porewater. Porewater, $\mathrm{pH}$ and salinity (measured as conductivity) were determined during the $25 \mathrm{~min}$ sampling period at two tidal amplitude conditions ( 2.4 and $3.9 \mathrm{~m}$ ). Meteorological conditions during most of the sampling periods were characterized by sunshine and no wind (daily mean, $6 \mathrm{~km} \mathrm{~h}^{-1}$ ), except during the $1.1 \mathrm{~m}$ tidal amplitude survey when the wind was stronger, the daily mean reached $18 \mathrm{~km} \mathrm{~h}^{-1}$. Site III was not inundated on every sampling, the water reached this area only when tidal amplitude was 
higher than $2.0 \mathrm{~m}$. At site A, located in the subtidal area (figure 1 ), bottom water was collected and dissolved ammonium was determined.

\subsection{Laboratory simulations}

In order to verify $\mathrm{NH}_{4}^{+}$desorption from sediments with the tidal flushing of the intertidal mudtlat area, laboratory simulations were performed by gently adding prefiltered estuarine water ( site A) to $8 \mathrm{~cm}$ diameter sediment cores. The sediments were collected at the three sampling sites in March 1994. The water overlying the sediment was carefully mixed using a stirring disk at two different speeds. The rotating speeds, 100 and 160 r.p.m., were applied to fresh sediment cores in a horizontal position for $25 \mathrm{~min}$, and water was sampled at the same time intervals as those used in the fieldwork. Sediments from site III were dried for three days, and the experiment was repeated with these sediment cores for the slower rotating speed, simulating the inundation of the lower salt-marsh area which remained exposed to the atmosphere over several neap tidal cycles.

\subsection{Analytical procedures}

In the laboratory, suspended particulate matter (SPM), dissolved ammonium $\left(\mathrm{NH}_{4}^{+}\right), \mathrm{pH}$ and salinity were determined in the flood water samples. Concentration of suspended particulate matter was determined by filtration of $100 \mathrm{~mL}$ of water through preweighed $0.4 \mu \mathrm{m}$ Nuclepore membranes. The membranes were dried for $24 \mathrm{~h}$ at $80^{\circ} \mathrm{C}$ and reweighed. Water samples were filtered (Millipore, $0.45 \mu \mathrm{m}$ ) and dissolved ammonium measured by the method described by Koroleff [14]. The detection limit of the method is $0.2 \mu \mathrm{M}$. The standard deviation for twenty samples containing a mean concentration of $19 \mu \mathrm{M}$ was found to be \pm 0.076 . The sediment pore water was separated from the solids by centrifugation and subsequent filtration (Millipore, $0.45 \mu \mathrm{m}$ ), and the filtrate analyzed for dissolved ammonium. Sediment water content was determined as the percentage of water in relation to total fresh weight, and organic matter content was evaluated as percentage of weight loss after ignition $\left(500^{\circ} \mathrm{C}, 3 \mathrm{~h}\right)$. Water content was calculated from the sediment weight loss at $105^{\circ} \mathrm{C}$ and porosity $(\phi)$ was calculated according to Berner [2]. Conductivity was measured with a Crison CDTM 523 conductimeter and $\mathrm{pH}$ with a Crison Micro $2002 \mathrm{pH}$ meter. For each parameter determination, three replicates per sample were made.

\section{RESULTS}

\subsection{Sediment characteristics}

Values of porosity, organic matter and $\mathrm{NH}_{4}^{+}$in porewater of surface sediments $(0-1 \mathrm{~cm})$ from sites I, II and III are shown in table $I$. The sediments consist mainly of line grain particles, as observed in many salt marshes of the estuary [6]. $\mathrm{NH}_{4}^{+}$concentration of porewater decreased from site $\mathrm{I}(88 \mu \mathrm{M})$ to site III $(44 \mu \mathrm{M})$. This spatial varia tion was observed throughout the neap-spring tidal cycle. At neap tides, surface sediments from site III were exposed to the air during a period of three days and porosity decreased to 0.3 due to the water lost by evaporation; $\mathrm{NH}_{4}^{+}$in the pore waters also decreased to $12 \mu \mathrm{M}$.

Table I. Mean values $(n=3)$ and standard deviation of porosity $(\phi)$. organic matter $(\%)$ and dissolved ammonium concentration $\left(\mathrm{NH}_{4}^{+}\right.$, $\mu \mathrm{M})$ in sediments from sites I. II and III, at an intermediate tide $(2.9 \mathrm{~m})$.

\begin{tabular}{lrrr}
\hline $\begin{array}{l}\text { Sediment } \\
\text { characteristics }\end{array}$ & \multicolumn{1}{c}{ Site I } & Site II & \multicolumn{1}{c}{ Site III } \\
\hline Porosity $(\phi)$ & $0.7 \pm 0.06$ & $0.7 \pm 0.01$ & $0.7 \pm 0.01$ \\
Organic matter $(\%)$ & $10 \pm 0.02$ & $9 \pm 0.01$ & $8 \pm 0.01$ \\
$\mathrm{NH}_{4}^{+}(\mu \mathrm{m})$ & $88 \pm 0.11$ & $75 \pm 0.11$ & $44 \pm 0.11$ \\
\hline
\end{tabular}

\subsection{Field surveys}

The intertidal sediments are periodically exposed to the atmosphere which may lead to a broad diurnal fluctuation of temperature. The arrival of tidal water after the period of air-exposure produced also a rapid alteration of temperature $\left(1-2^{\circ} \mathrm{C}\right)$. Figure 2 depicts the variation of temperature, salinity and $\mathrm{pH}$ in the flood water and in the sediment over the first 25 min of tidal inundation, at the three sampling sites. Temperature remained constant in the flood water but sharply decreased in the sediment during the first four minutes. Salinity and $\mathrm{pH}$ of flood water and sediment decreased over the $25 \mathrm{~min}$ sampling period.

Changes in water height at the three sampling sites over the 25 min sampling period are presented in figure 3 . No substantial differences were observed for the different tidal conditions, except in site $I 1$ when tidal amplitude was $1.1 \mathrm{~m}$. A similar pattern was observed for the three sites: water height increased faster in the first 5 min than during the following $20 \mathrm{~min}$. The slope of the line corresponding to the first $5 \mathrm{~min}$ decreased from site I to site III. 


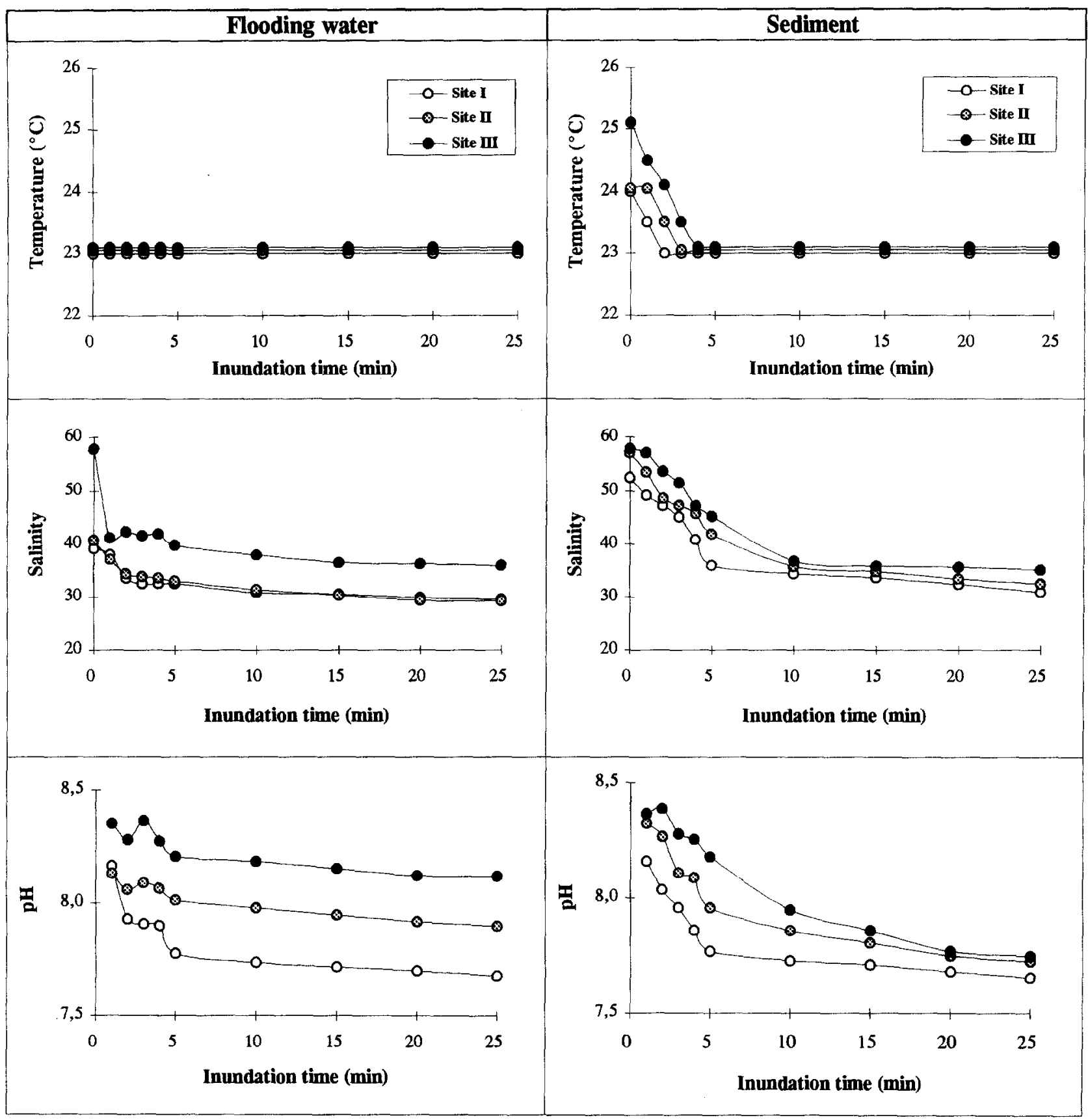

Figure 2. Evolution of temperature, salinity and $\mathrm{pH}$ in the flood water and scdiment over 25 min of tidal inundation at an intermediate tide $(2.4 \mathrm{~m})$, at the sites I, II and III.

Concentrations of suspended particulate matter at the three sites during the $25 \mathrm{~min}$ is presented in figure 4 . In each site, the highest values were recorded around $10 \mathrm{~min}$ after the inundation, during the highest tide $(3.9 \mathrm{~m})$. SPM concentrations in this tidal period decreased from site I (max. $83 \mathrm{mg} \mathrm{L}^{-1}$ ) to site III (less than $30 \mathrm{mg} \mathrm{L}^{-1}$ ).

With respect to $\mathrm{NH}_{4}^{+}$concentration in flood water, a general trend was observed for the different surveys and 


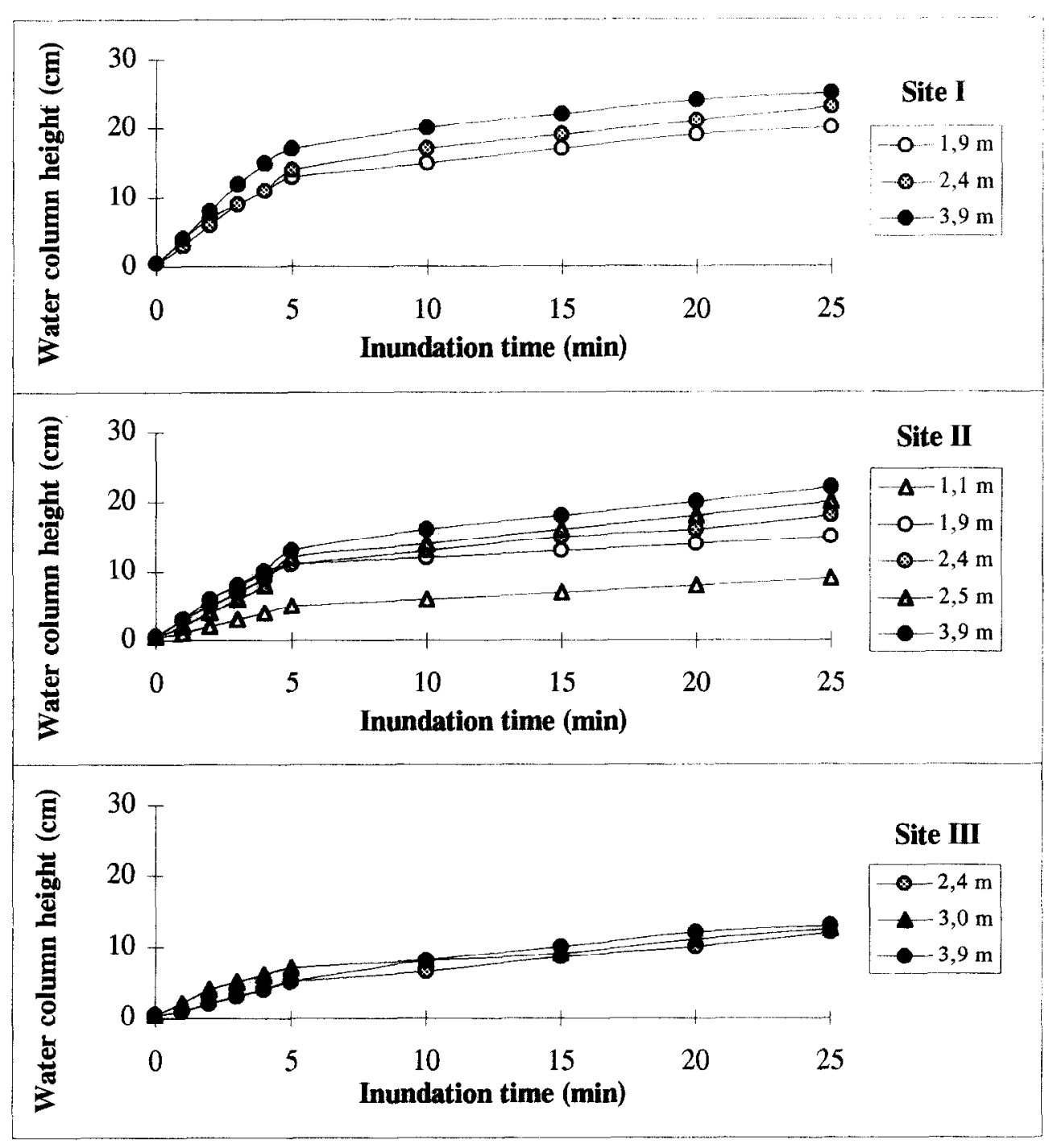

Figure 3. Water column height $(\mathrm{cm})$ measured at sites I, II and III during the first 25 min of the tidal inundation at different tidal amplitudes.

sites: concentration in water increased substantially, reaching a broad maximum at approximately $10 \mathrm{~min}$ after the inundation (figure 5). In site II, some irregularities were recorded in the first $5 \mathrm{~min}$, but the sharp, pronounced maxima was maintained. Levels of $\mathrm{NH}_{4}^{+}$ increased one order of magnitude during this short time interval, reaching values from 12 to $27 \mu \mathrm{M}$. In general, the peak of $\mathrm{NH}_{4}^{+}$concentration increased with tidal amplitude at the three sites. An exception was recorded at Site III in the $3.0 \mathrm{~m}$ tidal amplitude survey, which followed a 3 day period of intertidal sediment permanently exposed to the air. Concentrations of $\mathrm{NH}_{4}^{+}$remained around $4 \mu \mathrm{M}$, lower than the ones recorded for the $2.4 \mathrm{~m}$ survey. No observations were made at neap tides $(<1.9 \mathrm{~m})$ since this site was not inundated during this period of the tidal cycle. Under windy conditions, which occurred during the $1.1 \mathrm{~m}$ survey, the concentration of $\mathrm{NH}_{4}^{+}$in the flooding water at site II was higher and comparable to values found in spring tide periods.

There was a positive correlation between the flood water velocity and both concentration of $\mathrm{NH}_{4}^{+}$and SPM in the flood water (figure 6). However, $\mathrm{NH}_{4}^{+}$and $\mathrm{SPM}$ were poorly correlated $(\mathrm{r}=0.63 ; \rho<0.001)$ (figure 6 ).

The dissolved $\mathrm{NH}_{4}^{+}$concentrations in bottom water of the channel (site A, figure l) remained close to $4 \mu \mathrm{M}$. 


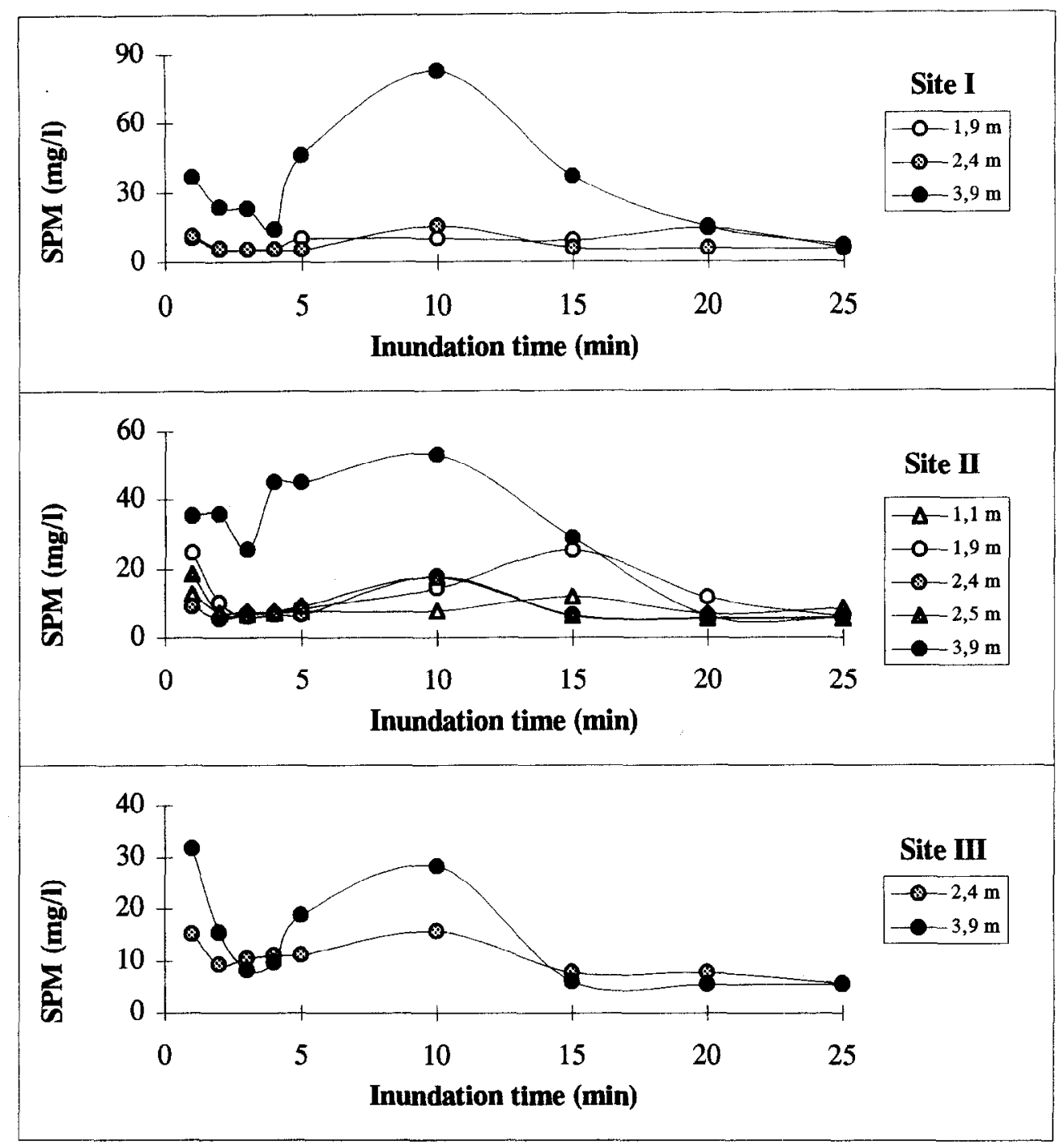

Figure 4. Concentration of suspended particulate matter (SPM, $\mathrm{mg} \mathrm{L}^{-1}$ ) in the flooding water at sites I, II and III during the first $25 \mathrm{~min}$ of the tidal inundation at different tidal amplitudes (notice the different scales).

\subsection{Laboratory simulations}

The laboratory experiments, conducted at the three sampling sites, confirmed that $\mathrm{NH}_{4}^{+}$was released from wet sediments into the water flooding over the sediment surface. The concentration of $\mathrm{NH}_{4}^{+}$in the overlying water increased continuously during the $25 \mathrm{~min}$, from $1 \mu \mathrm{M}$ to higher than $15 \mu \mathrm{M}$, and further increased with higher water mixing (from 100 to 160 r.p.m.) (figure 7a). SPM concentration varied from 12 to $28 \mathrm{mg} \mathrm{L}^{-1}$ during the $25 \mathrm{~min}$. The experiments, repeated with dry sediments from site III to simulate the $\mathrm{NH}_{4}^{+}$release from the sedi- ments developed after three days of air exposure, showed a lower release of $\mathrm{NH}_{4}^{+}$in the dry sediments, during the $25 \mathrm{~min}$ of the experiment (figure $7 \mathrm{~b}$ ). The differences between wet and dry sediments observed in these simulations are in accordance with the field results obtained at site III.

\subsection{Ammonium released from the intertidal sediment during the tidal flushing}

Based on the values presented in figure 5 and converting the $\mathrm{x}$-axis in water height (time:height ratio varied in 


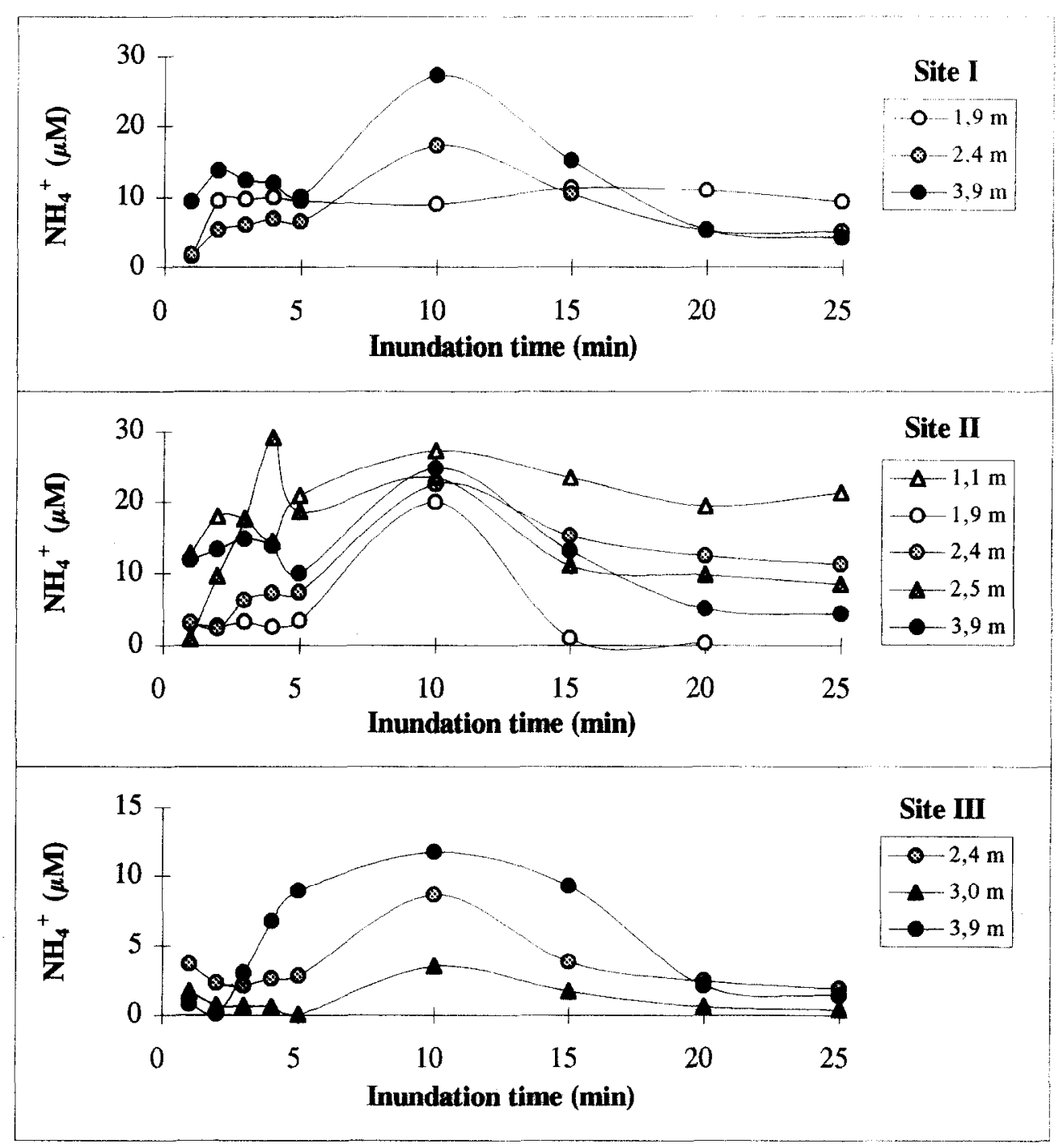

Figure 5. Concentration of dissolved ammonium $\left(\mathrm{NH}_{4}^{+}, \mu \mathrm{M}\right)$ in the flooding water at sites I, II and III during the first 25 min of the tidal inundation at different tidal amplitudes (notice the different scales).

each survey, figure 3), the transport of ammonium (Q) due to physical perturbation of the sediment surface during the first 25 min of tidal inundation may be estimated by the following expression:

$\mathrm{Q}\left(\mathrm{mmol} \mathrm{m} \mathrm{m}^{-2}\right)=\sum\left[\left(\mathrm{C}_{\mathrm{i}+1}+\mathrm{C}_{\mathrm{i}}\right) / 2\right] \cdot\left(\mathrm{h}_{\mathrm{i}+1}-\mathrm{h}_{\mathrm{i}}\right)$

where $\mathrm{C}_{\mathrm{i}}$ is the excess of $\mathrm{NH}_{4}^{+}$concentration in the flood water at minute $1,2,3,4,5,10,15,20$ and 25 after the first inundation, that is, the $\mathrm{NH}_{4}^{+}$concentration in flood water minus the residual concentration $\left(\mathrm{C}_{\mathrm{R}}\right) ; \mathrm{C}_{\mathrm{R}}$ is the residual $\mathrm{NH}_{4}^{+}$concentration in the water column (mini- mum value observed during the $25 \mathrm{~min}$ at each survey, figure 5), and $h_{\mathrm{i}}$ the water depth at each time of the flood. The quantity Q transported to the water column at sites I, II and III was calculated for the different tidal ranges (table II). Values varied between 0.1 and $2.4 \mathrm{mmol} \mathrm{m}^{-2}$, being the higher quantities recorded at Site $I$ and the lower at Site III. During the $3.9 \mathrm{~m}$ tidal survey the ammonium flushing was higher in all sites. Since the tides in the Tagus estuary are semi-diurnal, most intertidal areas are inundated twice a day, and consequently the quantity Q should be multiplied by two to be expressed on a daily basis. So, values ranged from 0.2 to $4.8 \mathrm{mmol} \mathrm{m}^{-2} \mathrm{~d}^{-1}$. 


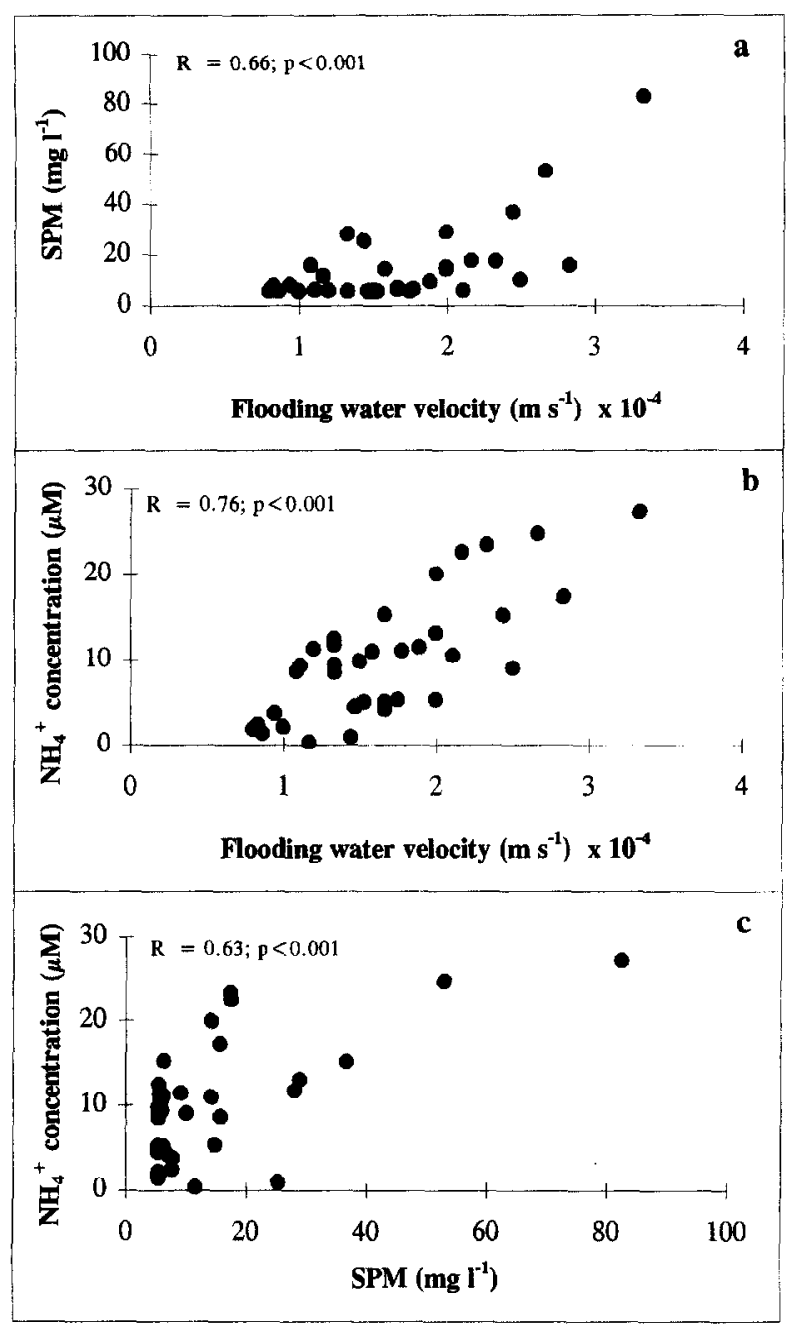

Figure 6. Relationship between flooding water velocity $\left(\times 10^{-4} \mathrm{~m} \mathrm{~s}^{-1}\right)$ and suspended particulate matter (SPM, $\mathrm{mg} \mathrm{L}^{-1}$ )

(a), flooding water velocity and dissolved ammonium $\left(\mathrm{NH}_{4}^{+}, \mu \mathrm{M}\right)$

(b), and suspended particulate matter and dissolved ammonium

(c), during the first 25 min of tidal inundation.

\subsection{Ammonium released from the submerged inter- tidal sediment by molecular diffusion}

The above-mentioned quantities were compared to the amount of ammonium crossing the sediment-water interface by molecular diffusion. Using Fick's 1st law of diffusion [2]:

$\mathrm{F}=-\phi \mathrm{D}_{\mathrm{s}}(\mathrm{Co}-\mathrm{Cp}) / \Delta \mathrm{x}$

one may calculate the flux $(\mathrm{F})$ of ammonium in the intertidal zone considering:

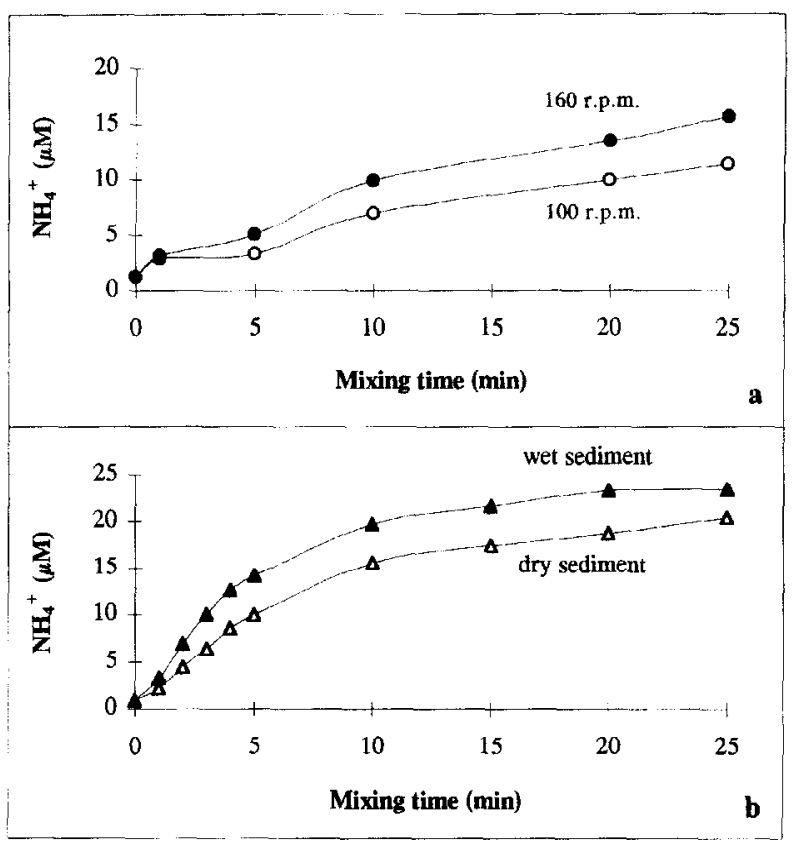

Figure 7. Concentration of dissolved ammonium $\left(\mathrm{NH}_{4}^{+}, \mu \mathrm{M}\right)$ in overlying water collected from (a) wet sediment cores, during $25 \mathrm{~min}$, at two different rotating speeds (100 and 160 r.p.m.), simulating different levels of physical perturbation of the sediment, and (b) dry and wet sediment cores, during $25 \mathrm{~min}$, at the same rotating speed ( 100 r.p.m.), simulating the inundation of sediment that remained exposed to the atmosphere during the neap tides.

Table II. Amounts of dissolved ammonium $\left(\mathrm{mmol} \mathrm{m}^{-2}\right)$ exported from sediments of sites I, II and III during the 25-min tidal flushing, at different tidal ranges.

\begin{tabular}{lccc}
\hline Tidal range $(\mathbf{m})$ & Site I & Site II & Site III \\
\hline 1.1 & - & 1.2 & - \\
1.9 & 1.0 & 0.5 & - \\
2.4 & 1.0 & 0.6 & 0.3 \\
3.0 & - & - & 0.1 \\
3.9 & 2.4 & 1.6 & 0.7 \\
\hline
\end{tabular}

$\phi=0.7$ for the studied sediments;

$\mathrm{D}_{\mathrm{s}}=9 \times 10^{-6} \mathrm{~cm}^{-2} \mathrm{~s}^{-1}$ for $\mathrm{NH}_{4}^{+}$, considering a temperature range of $20-25{ }^{\circ} \mathrm{C}$ [1];

$\mathrm{Co}=$ concentration of $\mathrm{NH}_{4}^{+}$in the overlying water, $4.0 \mu \mathrm{M}$ (mean value observed during a neap-spring tidal cycle in March);

$\mathrm{Cp}=$ concentration of $\mathrm{NH}_{4}^{+}$in the surface sediment porewater, 44-88 $\mu \mathrm{M}$ (table I);

$\Delta \mathrm{x}=$ distance across the sediment-water interface, $2 \mathrm{~cm}$.

The inundation periods at sites I, II and III were calculated based on the sinusoidal shape of the tidal height 
curve (table III). Due to the smooth slope of the intertidal zone, the flood period varied only slightly from neap to spring tides at sites I and II. Site III, the highest site, was more affected by the tide, particularly at the neapest tide $(1.1 \mathrm{~m})$, because sediments remained exposed to the atmosphere during the entire semi diurnal tidal cycle. Using inundation values, the expression (2) may, therefore, be used to estimate the daily diffusive flux at each site and for each tide (table $I V$ ). Diffusive transport of $\mathrm{NH}_{4}^{+}$varied between 0.07 and $0.16 \mathrm{mmol} \mathrm{m}^{-2} \mathrm{~d}^{-1}$. These values were lower than the $\mathrm{NH}_{4}^{+}$exported, as result of the short-term mixing over the intertidal sediment. In fact, by comparing the values in tables 2 and 4, one may conclude that mixing transport of $\mathrm{NH}_{4}^{+}$exceeds by one order of magnitude the $\mathrm{NH}_{4}^{+}$transported by molecular diffusion.

Table III. Time of inundation (hours day ${ }^{-1}$ ) at sites I, II and III of the intertidal area, at different tidal ranges.

\begin{tabular}{lccc}
\hline Tidal range (m) & Site I & Site II & Site III \\
\hline 1.1 & 12.4 & 11.4 & 0.0 \\
1.9 & 12.2 & 12.0 & 11.8 \\
2.4 & 12.2 & 12.0 & 11.8 \\
3.0 & 12.2 & 12.0 & 12.0 \\
3.9 & 12.2 & 12.2 & 12.0 \\
\hline
\end{tabular}

Table IV. Amount of dissolved ammonium (mmol $\mathrm{m}^{-2} \mathrm{~d}^{-1}$ ) exported from sediments of sites I, II and III to the water column by molecular diffusion.

\begin{tabular}{lccc}
\hline Tidal range (m) & Site I & Site II & Site III \\
\hline 1.1 & 0.160 & 0.120 & 0.000 \\
1.9 & 0.157 & 0.129 & 0.072 \\
2.4 & 0.157 & 0.129 & 0.072 \\
3.0 & 0.157 & 0.129 & 0.072 \\
3.9 & 0.157 & 0.131 & 0.072 \\
\hline
\end{tabular}

\section{DISCUSSION}

Short-term observations in a large mudflat area of the Tagus estuary highlighted sharp changes in physical and chemical parameters of the sediment during inundation of the area by the tide. Inundation causes a stress at the sediment-water interface that may go from mixing of the flood water over the sediment surface [13] to resuspension of fine particles. Because our data were obtained from the lower to the upper intertidal sediments, and under conditions covering a large tidal range and at two different wind conditions, they include the most represen- tative situations of flood water energy dissipation over the mudflat area. Under all these situations a common pattern was clearly defined: at the beginning of the inundation, $\mathrm{NH}_{4}^{+}$was exported from the sediment to the water column in considerable quantities 10.2 to $4.8 \mathrm{mmol} \mathrm{m}^{2} \mathrm{~d}^{-1}$ ). Such a pattern was also observed in a mesotidal coastal lagoon (south Portugal) with large intertidal areas 181. The $\mathrm{NH}_{4}^{+}$release was mainly induced by a physical mechanism, since infauna and gas bubbling were not observed.

In the lower part of the intertidal sediment, inundation follows the semi-diurnal tidal rhythm and occurs twice a day. This induces an export of $\mathrm{NH}_{4}^{+}$at the same rhythm. In order to balance this export, nitrogen should be almost continuously supplied to the sediment. In fact, $\mathrm{NH}_{4}^{+}$is rapidly consumed by the primary producers in the water column of estuarine areas $[12,15]$. The average consumption of the Tagus phytoplankton population near the sampling area was estimated as $0.5 \mu \mathrm{M} \mathrm{h}^{-1}$ [4]. This value indicates that $\mathrm{NH}_{4}^{+}$is constantly consumed in the Tagus estuary, and is not accumulating in the water column. In intertidal sediments, it is expected that organic matter, which is derived from phytoplankton, benthic communities and also salt-marsh plants, decomposes thus leading to the production of $\mathrm{NH}_{4}^{+}$[3]. Furthermore, a significant production of organic matter in the water column occurs in spring and summer [5]. which is exported to the sediment surface, when grazing by the zooplankton in the water is delayed. The alternate air exposure of the intertidal sediment of the Tagus estuary creates conditions for daily variation of temperature in the upper sediment layers (figure 2). Since $\mathrm{NH}_{4}^{+}$production is a function of the temperature, a daily $\mathrm{NH}_{4}^{+}$input can be expected in the water column. In Ria Formosa, it was found that $\mathrm{NH}_{4}^{+}$production follows the temperature fluctuation on a semidiurnal time scale [26]. Tidal flushing of ammonium from intertidal sediments probably removes the $\mathrm{NH}_{4}^{+}$produced in the upper sediment layers on similar time scales.

The dominant process influencing $\mathrm{NH}_{4}^{+}$concentration in the porewater of marine sediments is degradation of organic matter, but reversible ion-exchange on sediment particles also affects the levels present in porewater [19]. This process was found to be independent of the temperature. However, the equilibrium may be continuously readjusted in intertidal sediments due to physical mechanisms. Percolation in sediments was demonstrated to renew porewater in the upper sediment [13]. Variations of salinity and $\mathrm{pH}$ in sediments at the beginning of the inundation (figure 2) confirm that renewal mechanisms are effective in the intertidal Tagus mudflats and induces an 
export of $\mathrm{NH}_{4}^{+}$from the sediment. The percolation in those upper layers may cause alterations in the existing equilibrium between porewater and sediment solids and consequently modify the $\mathrm{NH}_{4}^{+}$sorption equilibrium. These alterations in the liquid-solid equilibrium were observed during the inundation of Ria Formosa mudflats [7]. The laboratory experiment demonstrated that $\mathrm{NH}_{4}^{+}$is rapidly removed from the sediment solids, as sea water gently mixes in the surface sediment, and thus this removal increases with the intensity of the physical perturbation of the sediment (figures 5, 7a). The linear relationships found between the flooding water velocity, SPM and $\mathrm{NH}_{4}^{+}$concentration show the importance of the physical perturbation on sediment resuspension and on $\mathrm{NH}_{4}^{+}$release. Presumably $\mathrm{NH}_{4}^{+}$originates mainly in porewater. A strong current and a higher tidal amplitude cause a deeper penetration of seawater into the sediment resulting in an upward transport of $\mathrm{NH}_{4}^{+}$produced in the deeper section of the sediment. The poorer relationship between SPM and $\mathrm{NH}_{4}^{+}$suggests that their source is different. However, the possibility of $\mathrm{NH}_{4}^{+}$removal from the sediment solids should not be excluded during spring tides and windy conditions due to the nature of $\mathrm{NH}_{4}^{+}$association to particles (reversible ion-exchange). Resuspension of intertidal sediments by the tidal currents and windwave forcing is widely observed, resulting in short-term increases and decreases of suspended particulate matter $[18,23]$ and causing $\mathrm{NH}_{4}^{+}$desorption from sediment solids to the water column [24]. Such a breakdown of steady-state conditions has been observed in other coastal systems due to seasonal changes in the sediment [27].

The inundation periods of the Tagus upper intertidal area vary fortnightly, with the amplitude of the tide. At neap tides, the upper intertidal zone remains exposed to the air for longer periods than at spring tides when it is daily inundated. There are considerable differences from site I (lower part of the mudflat) to site III (upper part) in terms of $\mathrm{NH}_{4}^{+}$fluxes. Comparisons between sites revealed that predicted diffusion fluxes decreased $50 \%$ from site I to III. The flushing of $\mathrm{NII}_{4}^{+}$also decreased considerably, e.g. from 1.9 to $0.6 \mathrm{mmol} \mathrm{m}^{-2} \mathrm{~d}^{-1}$ at an intermediate tide (2.4 m). After neap tide, and consequently longer periods of air exposure (three days), a stronger decrease of $\mathrm{NH}_{4}^{+}$ export was observed in the upper part of the intertidal area $\left(0.2 \mathrm{mmol} \mathrm{m}^{-2} \mathrm{~d}^{-1}\right)$. The decrease suggests that less exchangeable $\mathrm{NH}_{4}^{+}$is available in the sediment during the drying period. The major process involved is not known, local consumption by primary benthic producers, nitrification and denitrification, and loss of nitrogen in gaseous forms may all play an important role. For example, the loss of $\mathrm{NH}_{4}^{+}$from the sediments is well known from dried aquaculture ponds [11]. The $\mathrm{NH}_{4}^{+}$flushing increased at periods of spring tide due to the stronger bottom resuspension. In spite of the fortnightly fluctuations of both transports in the intertidal zone, the flushing was much higher (ranging from $0.2-4.8 \mathrm{mmol} \mathrm{m}^{-2} \mathrm{~d}^{-1}$ ) than the molecular diffusion alone $\left(0.07-0.16 \mathrm{mmol} \mathrm{m}^{-2} \mathrm{~d}^{-1}\right)$.

This study clearly shows that $\mathrm{NH}_{4}^{+}$flushing from intertidal sediments during inundation by tides played an important role in accelerating recycling of inorganic nitrogen for the benefit of the primary producers in the Tagus estuary.

\section{Acknowledgments}

This work was co-financed by JNICT through the PhD Grant BD/2166/92-IG, to M.T.C. The authors are grateful to C. Mestre and J. Cruz for assistance in the field work and wish to thank Dr. Boutler and three anonymous referees for constructive criticism and M. Falcão for critical reviews on the typescript.

\section{REFERENCES}

[1] Aller R.C., Diagenetic processes near the sediment-water interface of Long Island Sound, Decomposition and nutrient element geochemistry (S, N, P), Adv. Geophys. 22 (1980) 237-350.

[2] Berner R.A., Early diagenesis - A theoretical approach, University press, Princeton, U.K., 1980, 241 p.

[3] Blackburn T.H., Henriksen K., Nitrogen cycling in different types of sediments from the Danish waters, Limnol. Oceanogr. 28 (3) (1983) 477-493.
[4] Cabrita M.T., Inorganic nitrogen dynamics in the Tagus estuary (Portugal). Spatial and temporal variation in input and uptake of nitrate and ammonium, Ph.D. thesis, Lisbon University, 1997, $132 \mathrm{p}$.

[5] Cabrita M.T., Moita M.T., Spatial and temporal variation of physicochemical conditions and phytoplankton during a dry year in the Tagus estuary (Portugal), Neth. J. Aquat. Ecol. 29 (3-4) (1995) 323-332. 
[6] Caçador I., Acumulação e retenção de metais pesados nos sedimentos dos sapais do estuário do Tejo, Ph.D. thesis, Lisbon University. 1994, $142 p$.

[7] Falcão M., Dinâmica dos nutrientes na Ria Formosa: efeitos da interacção da laguna com as suas interfaces na reciclagem do azoto, fósforo e sílica, Ph.D. thesis, Algarve University, 1997 $223 \mathrm{p}$.

[8] Falcão M., Vale C., Tidal flushing of ammonium from intertidal sediments of Ria Formosa, Portugal, Neth. J. Aquat. Ecol. $29(3-4)(1995) 239-244$.

[9] Fanning K.A., Carder K.L., Betzer P.R., Sediment resuspension by coastal waters: a potential mechanism for nutrient recycling in the ocean's margins, Deep-Sea Res. 29 (8A) (1982) 953-965.

[10] Fernex F., Baratie R., Span D., Fernandes L.V., Variations of nitrogen nutrient concentrations in the sediment pore waters of the northwestern Mediterranean continental shelf, Cont. Shelf Res. 9 (9) (1989) 767-794.

[11] Gouleau D.. Feuillet-Girard M., Germaneau J., Robert S., Effets de l'assèchement des bassins ostréicoles sur le cycle biogéochimique de nutriments azotés: ammonification préférentielle, Oceanol. Acta 19 (2) (1996) 101-115.

[12] Kanda J., Ziemann L.D., Conquest L.D., Bienfang P.K., Nitrate and ammonium uptake by phytoplankton population during the spring bloom in Auke Bay, Alaska, Estuar. Coast. Shelf Sci. 30 (1990) 509-524.

[13] Kerner M., Wallmann K., Remobilization events involving Cd and $\mathrm{Zn}$ from intertidal flat sediments in the Elbe estuary during the tidal cycle, Estuar. Coast. Shelf Sci. 35 (1992) 371 393.

[14] Koroleff F., Direct determination of ammonia in natural waters as indophenol blue, Int. Counc. Explor. Sea (ICES), Pap. C.M. 1969/C:9; revised $1970(1969 / 1970) 19-22$.

[15] Kristensen E., Seasonal variations in benthic community metabolism and nitrogen dynamics in a shallow, organic-poor Danish lagoon, Estuar. Coast. Shelf Sci. 36 (1993) 565-586.

[16] Lerat Y., Lasserre P., Corre P., Seasonal changes in pore water concentrations of nutrients and their diffusive fluxes at the sediment-water interface, J. Exp. Mar. Biol. Ecol. 135 (1990) $135-160$.

[17] Lomstein B.A., Blackburn T.H., Henriksen K., Aspects of nitrogen and carbon cycling in the northern Bering Shelf scdi- ments, I. The significance of urea tumover in the mineraliza tion of $\mathrm{NH}_{4}^{+}$. Mar. Ecol. Prog. Ser. 57 (1989) 237-247.

[18] Luettich R.A. Jr., Harleman D.R.F., Somyódy L., Dynamic behavior of suspended sediment concentrations in a shallow lake perturbed by episodic wind events, Limnol. Oceanogr, 35 (5) (1990) 1050-1067.

[19| Mackin J.. Aller C., Ammonium adsorption in marine sediments, Limnol. Oceanogr. 29 (2) (1984) 250-257.

[20] Nixon S.W. Between coastal marshes and coastal waters - a review of twenty years of speculation and research on the role of salt marshes in estuarine productivity and water chemistry, in: Hamilton P., MacDonald K.B. (Eds.), Estuarine and wetland process Plenum Publ. Corp. New York, 1980, 437-525.

[21] Nowicki B.L.. Nixon S.W., Benthic nutrient remineralization in a coastal lagoon ecosystem. Estuaries 8 (2B) (1985) 182 190 .

[22] Rocha C., Rhythmic ammonium regeneration and flushing in intertidal sediments of warm climates. Limnol. Oceanogr. in press.

[23] Sandford L.P., Wave-forced resuspension of upper Chesapeake Bay muds, Estuaries 17 (1B) (1994) 148-165.

[24] Simon N. S., Nitrogen cycling between sediment and the shallow-water column in the transition zone of the Potomac river and estuary, II. The role of wind-driven resuspension and adsorbed ammonium, Estuar. Coast. Shelf Sci. 28 (1989) 531 547 .

[25] Vale C., Sundby B., Suspended sediment fluctuations in the Tagus estuary on semi-diurnal and fortnightly time scales. Estuar. Coast. Shelf Sci. 25 (1987) 495-508.

[26] Vale C., Hussenot J., Falcão M., Martin J.-L., Dawn-dusk chemical variations near the sediment-water interface of a clamgrown bank of Ria Formosa, Seminário sobre aquacultura mediterrânica-Portugal, 19 (1992) 71-79.

[27] Vidal M., Morguí J.-A., Short-term pore water ammonium variability coupled to benthic boundary layer dynamics in Alfacs bay, Spain (Ebro Delta, NW Mediterranean), Mar. Ecol. Prog. Ser. 118 (1995) 229-236.

[28] Yamada H., Kayama M., Fujisawa K., Seasonal changes of concentrations of inorganic and organic nitrogen in coastal marine sediments, Estuar. Coast. Shelf Sci. 24 (1987) $585-$ 598 . 